\section{EMBRYRIDDLE}

Aeronautical University

SCHOLARLY COMMONS
Journal of Aviation/Aerospace Education \& Research

Volume 2

Number 1 JAAER Fall 1991

Article 14

Fall 1991

\title{
The FAA and Aviation Education
}

Phillip S. Woodruff

Follow this and additional works at: https://commons.erau.edu/jaaer

\section{Scholarly Commons Citation}

Woodruff, P. S. (1991). The FAA and Aviation Education. Journal of Aviation/Aerospace Education \& Research, 2(1). https://doi.org/10.15394/jaaer.1991.1062

This Article is brought to you for free and open access by the Journals at Scholarly Commons. It has been accepted for inclusion in Journal of Aviation/Aerospace Education \& Research by an authorized administrator of Scholarly Commons. For more information, please contact commons@erau.edu. 
What has been needed desperately for many, many years is a refereed journal devoted to issues that the aviation/aerospace community, be it the industry or the educational institutions, see as critical. A refereed journal is a publication that uses a blind review process for manuscripts that are submitted for consideration for publication. JAAER uses a minimum of three peer reviewers for each manuscript. Each reviewer is a subject matter specialist and/or a practicing professional in that field. Each referee indicates whether the manuscript should be accepted for publication, accepted with revisions, or rejected; the editor makes a final decision and informs the author.

As you are aware, there is now a refereed journal for the aviation/aerospace community. As far as the "how did we do it", I must say it was done with little money and a lot of sweat equity. My institution has graciously supported the Journal since our first issue was published in April of 1990. However, the expectation is that in the future most of our support will come from subscriptions and donations.

I am pleased to announce that during the first fiscal year, May 1 to April $30,79.5 \%$ of the Journal budget is derived from subscriptions and only $20.5 \%$ is funded by ERAU funds. The Journal has over $\mathbf{2 3 0}$ professional members, 6 institutional libraries as subscribers, and 5 student memberships.

Of our total budget, $40 \%$ is for administrative and secretarial support, $35 \%$ is for printing costs, $10 \%$ is for travel, and $5 \%$ is for general supplies. For the next fiscal year, I have submitted a budget which reflects three issues per year rather than I hope that within the next years, we can publish on a quarterly basis.

I would like to encourage you and your organization to consider becoming a sustaining sponsor for the Journal. It is imperative that $I$ begin to establish a base of minimum support that will serve as a foundation. Perhaps your organization might be able to help us with a small grant this next fiscal year. The minimum cost for any of these programs is a few hundred dollars. We do not advertising but are very willing to list you conspicuously as a sponsor.

The need for the sharing of ideas among university aviation educators and with individuals in our government and the aviation industry has never been more important than it is today. As we all know, the air transportation system, particularly since deregulation, has grown as few could have imagined. With this growth has come a need for the aviation industry and higher education to work jointly to solve a number of exceedingly pressing problems. One of the best ways to solve many of these problems will be through communication in the form of an exchange of ideas.

The Journal of Aviation/Aerospace Education and Research stands ready to assist this effort. Can we count on your help?

\title{
THE FAA AND AVIATION EDUCATION
}

\author{
Phillip S. Woodruff
}

First, I want to compliment GAMA, and especially Frank Mitchell, for arranging this "Issues" luncheon--and I want to thank each of you for your participation in and contribution to the success of this event. I hope we are able to continue such forums for many years to come. This conference is much different from most of the events that many of us attend throughout the year. For example, rather than speak about WHAT we do at FAA, Frank asked me to explain WHY we at FAA do what we do in terms of aviation education.

I suppose that's a fair question, and I'll do my best to give you an answer in the few minutes that we have to share together, but that task is a bit like asking me to describe the universe and give two examples.

Actually it is a very fair question, not only for the Federal 
government but for all of us.

Issues in aviation education on the national, state, local, and individual levels, in government, industry, and education, are not being addressed as directly as they should be addressed. Perhaps it is time that we all reassess what we are doing and why we are doing it in order to determine if we are accomplishing our individual and collective missions effectively.

I think such an analysis would reveal that most of us are doing a fairly good job of accomplishing our individual programs and missions, but I suspect that such an assessment would also show that we, as a group of organizations with allied interests, have not worked as closely together as we should to accomplish the overall objectives of aviation education in the United States.

To understand why FAA, or any of us for that matter, do what we do in aviation education requires that we understand the purpose, or mission, of the organization as well as its culture, processes, and resources. I don't plan to take a lot of time trying to explain all of that today, but since we are talking about issues, it is relevant to make this point lest we misunderstand why we do what we do. Perhaps understanding each other is high on the list among the major issues in aviation education today.

We might ask why there is an FAA. Before 1926 the federal government assumed none of the responsibilities that now belong to FAA.

Some states licensed pilots, but there were no nationwide standards for pilots, for airworthiness (of aircraft), or for air traffic control. Those were days when airport operators used flags and lights to provide air traffic services. When a pilot with a history of recklessness buzzed a crowd right down the street here in Washington, D.C. while President Harding was dedicating the Lincoln Memorial, no action was taken against the pilot, for he had violated no rule. It is true that at that time the post office department was developing a system of ainways marked by navigational aids. Just think about that for a moment. What if the Air Commerce Act of 1926 had not passed? But it did pass, and that work [navigational aids] was taken over by the aeronautics branch of the Department of Commerce, creating the FAA's first predecessor agency and involving the federal government in the certification of airmen and aircraft, as well as in other safety and promotional activities.

This demand for change, the demand for federal regulation, came from members of the aviation community who realized that their industry could not grow unless it was recognized as a serious enterprise rather than a collection of unsafe war surplus airplanes flown by Laisse Faire pilots and "barnstormers."

Even after the 1926 Air Commerce Act passed, it was the airlines who established and maintained the enroute centers. It became obvious during the next ten years that the federal government was best suited to run a uniform air traffic system. Federal operation began in 1936, and federal operation of airport towers following during World War II.
In the 1950s, with the introduction of jet airline service, it became apparent that the ongoing growth of civil aviation would soon make the existing system obsolete. The tragic collision of two airliners over the Grand Canyon in 1956 confirmed the problem and hastened the creation of a new, more powerful aviation agency.

Since its birth in 1958 the FAA has taken on many responsibilities. To ensure that flying retains its indispensable margin of safety, the FAA constantly applied new technology and procedures to keep pace with aviation's dynamic development.

Today, the FAA's purpose is to promote and regulate civil aviation in the United States in order to provide the nation with a safe and efficient air transportation system for the public.

Briefly, that is who we are and generally speaking is why we do what we do. But I want to explore with you for a moment, more specifically, why we do what we do.

We do many things because we are directed to do them by higher authorities in the government. We do other things because we want to do them, and we do some things because we must react to other situations which occur around us.

My years of experience in the aviation industry, government, and education lead me to believe that we are all quite alike in this regard.

So, Frank's question is perhaps best answered by stating that we do what we do because (a) we want to do it, (b) we have to do it, or (c) we react with what seems the best thing to do at 
the time. Again, I'm suggesting that a close assessment may show that we all operate, more or less, along these lines.

To speak directly to aviation education issues, I can tell you that the aviation education programs we offer are based exclusively on what we are directed to do by Congress and the administration. To do otherwise would be contrary to our purpose. On the other hand, we have made wide latitude in the creation of specific initiatives to accomplish the aviation education mission outlined by congress and the administration. Virtually all of the FAA's aviation education programs are designed, tested, and implemented by the aviation education program staff at FAA headquarters in cooperation with out regions, centers, and facilities throughout the country as well as with our partners in industry and education.

l'd like to take a second to introduce a few members of the FAA headquarters aviation education team: Mary Jo Byberg, Josie Clark, Latisha Mason, and Patrick Grubbe. They are a terrific group of talented and dedicated government workers, and they are the FAA aviation education program. I heard the other day that the term "government worker" was an oxymoron. I promise you that's not the case with this group. Sometime when you call me and get my answering machine, just press " $O$ ' and soon you'll be connected to someone who really knows what's going on.

Congress has charged the FAA with the responsibility for aviation education. Admiral James B.
Busey, the FAA administrator, stated his objective in aviation education like this:

Our goal is to provide increased awareness of civil aviation in order to promote intelligent, informed decisions about aviation by citizens and community leaders. . . to promote an aviation aware society which understands and respects the economic importance of aviation at the national community levels.

Admiral Busey further states that FAA will expand its aviation education initiatives through partnerships with the private sector, states, communities, and all levels of education.

Deputy Administrator Barry Lamber Harris convened the FAA aviation education task force last year to assess what we are doing in aviation education and to prepare a blueprint for the agency to accomplish this objective.

The task force communicated with all segments of the FAA, with the aviation industry, with the governors of each state, and with educational institutions, associations, and agencies. The task force has now completed its review of all the data collected and we have presented a plan for changing the course of aviation education in America. The new FAA aviation education program focuses on the role of FAA as leader, in partnership with industry and education to achieve our mutual national goals.

Over 50 initiatives have been proposed. They range from new programs for youth to new programs for entire communities and states. The common element in all of our programs is that we aspire to accomplish them in cooperation with other government entities and with leaders in education and industry.

We have already expanded our partnerships with the states through a formal partnership with the National Association of State Aviation Officials (NASAO) and with the helicopter association (HAl and AHS). We are well on our way to establishing a new partnership with general aviation through GAMA. We want to meet with each association and outline specific programs which we can accomplish together, programs and activities which could not otherwise be done as effectively or as cost-efficiently.

We are listening, we are taking action, and we are doing the things we should be doing. It's working.

The FAA is applying high technology to our programs. We are introducing computer-based instruction programs for schools. The new electronic clearinghouse for aviation education, FEDIX, is now on-line, and 3 million teachers can dial into the network and access and print out information from the central data base. Space has been set aside to include specialized information for each state and for each aviation association. This new system also includes general information about FAA and specific information on procurements and job openings. It also has a frequently updated aviation education news feature.

With the help of industry leaders and professional educa- 
tors, we are revising the FAA aviation education curriculum guides and the aviation career series publication.

We are planning to appoint our fiftieth aviation education resource center this year, and to begin satellite broadcast programs for education soon.

FAA will sponsor as many as 20 new "Ace Academy" programs for youth this summer, which is a summer camp where high school students can live on a college campus for a week, design airplanes with computers, visit airports, towers, FBO, and airline facilities. Most of them will have the opportunity to actually pilot an airplane. As in all of our programs, we especially encourage participation by women and minorities.

This fall we will host the nation's first aviation magnet school conference to bring together the growing number of educational systems which are operating and planning totally aviation oriented schools. A public high school in Virginia now owns its own airplane and simulators, and students can graduate with private pilot certificates.

In conjunction with an aviation museum, a new public high school is being built on airport property in Arkansas. When this school opens in 1991, some 1200 students will be offered a wide variety of aviation related curricula in a totally aviation oriented environment.

In closing, let me say that I hope we will all work together as partners in aviation education in the 1990s, even more than we have done in the past.

You industry and education leaders will be asked to work with us, to become partners in aviation education. We will listen. We will act. Together we change the direction of aviation education in America! Then we will have better educated citizenry and that will improve the quality of decisions made regarding aviation in this country at all levels of government and within industry and education.

The one thing I ask each of you here today is to reassess your aviation education mission, develop an ideal program for your organization, then talk to us about ways in which we may be helpful. Through this process we will make a greater contribution to aviation education than many of us ever dreamed possible.

As we approach the year 2000 , let us be sure that this decade is remembered as the period of time when we in government, industry, and education joined together to bring priority, order, purpose, and cohesion to aviation education.

We will do it not just because it is required, or because it is necessary to react to some event. We will do it because we want to do it, because it is the right thing to do, and because it will work.

Frank G. Mitchell, at Cessna Aircraft he engineered the development of the aviation industry's first comprehensive aviation education program. He later developed and managed Cessna's domestic and international flight training programs. He now directs Beech Aircraft Corporations's aviation education programs. Mr. Mitchell is a member of the Kansas Commission on Aerospace Education and currently serves as chairman of the General Aviation Manufacturers Association (GAMA) Education Committee.

Peggy Baty is currently the Academic Dean and Vice-President of Parks College in Cahokia, IL. Dr. Baty received her doctorate in education from the University of Tennessee-Knoxville. At national conferences, she is a frequent presenter on the subject of women in aviation.

Thomas J. Connolly, Professor of Aeronautical Science at Embry Riddle Aeronautical University, Daytona Beach, earned his Ed.D. at Nova University. In 1989 he was national winner of FAA's Administrator's Championship award for Excellence in Aviation Education at the graduate level. Dr. Connolly has been published a number of times, and for ten years he has been working on problems related to pilot judgment. 